\title{
THE EFFECT HOLDING TIME VARIATION ON THE PROCESS OF HEAT TREATMENT AUSTEMPERING ON MECHANICAL PROPERTIES AND MICRO STRUCTURES OF LATERITE STEEL
}

\author{
Djoko Setyo Widodo ${ }^{1}$, Desiran Sembiring ${ }^{2}$ and Bintang Adjiantoro ${ }^{3}$ \\ ${ }^{1}$ PhD Student Faculty of Mechanical Engineering Program of Technology \\ University of Malaysia and Lecturer at Universitas Krisnadwipayana, Indonesia \\ ${ }^{2}$ PhD Student Faculty of Mechanical Engineering Program Technology \\ University of Malaysia \\ ${ }^{3}$ Metallurgical Research Center LIPI, Serpong PUSPIPTEK Complex \\ ${ }^{1}$ djokosetyowidodo@gmail.com, ${ }^{2}$ desmuham@gmail.com, \\ ${ }^{3}$ bintangadjiantoro@yahoo.co.id
}

\begin{abstract}
The development of laterite steel is now being discussed by various research institutions. This cannot be separated from the potential of laterite-based steel into national steel. This study uses the austempering heat treatment process with variations of holding time austempering for 30,60 , and 90 minutes and using Zn (Zinc) cooling media. The characterization of laterite steel was carried out by testing hardness, impact resistance, microstructure, scanning electron microscopyenergy dispersive spectroscopy. The results showed an impact resistance value decreased 8.46 which was initially $209 \mathrm{~J}$ to $191.3 \mathrm{~J}$. Besides that the hardness value increased $36.58 \%$ from initially $164 \mathrm{HV}$ to $224 \mathrm{HV}$. Judging from its physical properties, the microstructure formed by pearlite ferrite bainite at a 90 -minute holding time while the results of the fracture are included in the ductile fracture because there are dimple holes and look blurry or dark.
\end{abstract}

Keywords - Laterite steel, heat treatment austempering, hardness, impact resistance, microstructure

\section{INTRODUCTION}

The development of laterite steel is now a topic of discussion by various research institutions, one of which is the Indonesian Knowledge Institute (LIPI), the Metallurgical and Materials Research Center (P2MM) for its potential to become national steel. According to Barkas in Hasbi et al's 2016 study, generally, laterite nickel ore is used as an alloy in the manufacture of stainless steel, the application of superalloys and alloy metals to increase corrosion resistance. With iron content of 35-45\% and nickel $0.8-1.5 \%$, after being processed into steel, laterite nickel ore in the form of Nickel Pig Iron (NPI) will produce steel with a nickel content of 2-3\% (Binudi and Adjiantoro, 2013).

The research on compartment of austempering and quenching and tempering processes for carburized automotive, explained the austempering process as a method that could possibly replace quench and tempering in the treatment of SAE 8620, 4320 and 8822 steels because this process can reduce distortion and be more economical (Andrew Clark, 2013 ) Najeeb Niazi (2014) also conducted a study on austempering heat treatment of

Received: July 1, 2019

Reviewed: October 10, 2019

Accepted: October 15, 2019

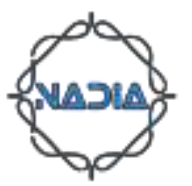


AISI 437 in this study, the higher and longer the time the austempering can increase the hardness and impact toughness of AISI 4340 steel. The effect of the austempering process on Nodular cast iron with variation and time can produce residual austenite bainite microstructures (Furqon and Hafid, 2012). According to Zdzislaw Lawrynowicz (2016) in his study of the bainite transformation during the austempering of ductile cast iron, the results of optical microscope testing were that bainite ferrite growth could continue to a greater extent and not only pure austerity but also a mixture of ferrite bainite, austenite and carbide.

As a step to find out some of the aspects possessed by laterite steel in terms of its potential, research will be conducted one of which is through the austempering heat treatment process. With variations in holding time austempering and characterization are carried out. The austempering heat treatment process, where rapid cooling of the austenite phase to the isothermal transformation area must be as fast as possible (C-D). This is to avoid the perlite phase so that maximum toughness and tenacity can be achieved. The temperature on the isothermal transformation (D-E-G) is above the temperature of martensite starts, while the isothermal transformation takes place in two stages. The first stage (D-E) is transformed from austenite to ferrite and the target area by diffusion of C atoms into regions with stable austenite. Stage two (E-G) transforms from remaining austenite to bainite and iron carbide. Like the scheme is shown in Figure 1. In this study the temperature of martensite start can be searched by the following equation:

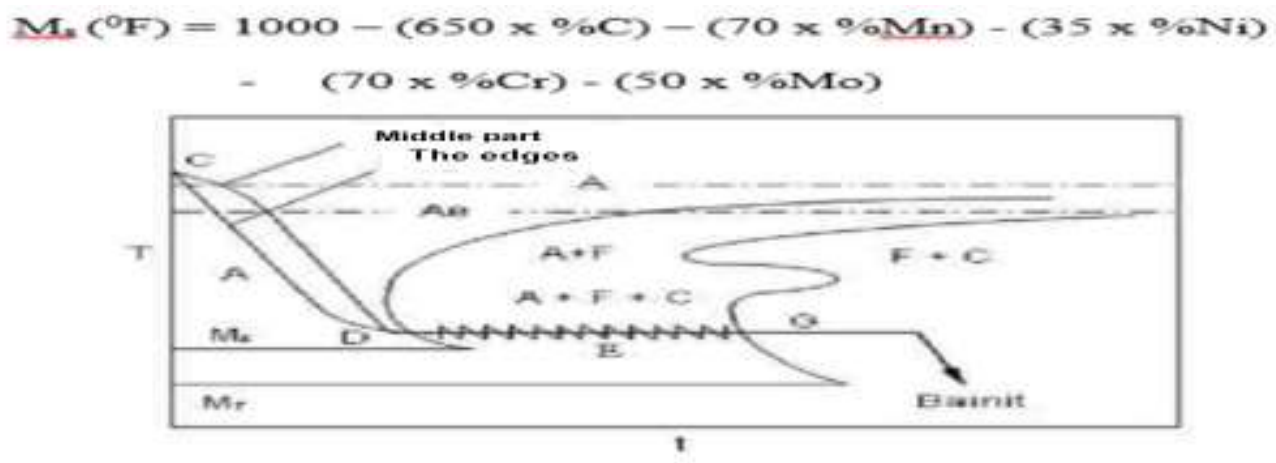

Fig. 1 Austempering Process Scheme (Sumber Raharjo, 2007: 45)

The appropriate heat treatment austempering process must be considered for the selection of the dye media. In the austempering process, the dyeing temperature is around $320-550^{\circ} \mathrm{C}$ so that a non-evaporation dyeing medium is needed at the temperature region. In the research that will be carried out the austempering cooling media used is the element Zinc $(\mathrm{Zn})$ which has a melting point of $419^{\circ} \mathrm{C}$ and a vapor point which reaches $907^{\circ} \mathrm{C}$ (sciencelab.com) with the austempering process at a temperature above Ms temperature of around $250-550^{\circ} \mathrm{C}$. Therefore in this study, the author discusses the effect of holding time variations on the austempering heat treatment process on the mechanical properties and microstructure of laterite steel.

\section{RESEARCH METHOD}

This study uses an experimental method to look for certain treatments for others in controlled conditions (Sugiyono, 2012: 72). The treatment carried out in this study is the austempering process and the results obtained in the form of Vickers hardness value, impact resistance value, microstructure formed, and the shape of the fracture that occurs.

In this study, the specimens used were laterite steel castings made at the Metallurgical Research Center and Materials of the Indonesian Institute of Sciences. The laterite steel needed in this study has a carbon composition of $0.2 \%$ wt with chemical analysis using 
spectroscopy. Laterite is a result of weathering that lasts very long from ultra-alkaline rocks. One of the laterites is laterite iron ore which is the main mineral of laterite iron ore is Goethite, $\left(\mathrm{Fe}_{2} \mathrm{O}_{3} \cdot \mathrm{H}_{2} \mathrm{O}\right)$ other minerals are Kwarsa $\left(\mathrm{SiO}_{2}\right)$, Hematite $\left(\mathrm{Fe}_{2} \mathrm{O}_{3}\right)$, Nickel Oxide (NiO) and Chromite $\left(\mathrm{Cr}_{2} \mathrm{O}_{3}\right)$. Laterites are classified into two types, namely saprolite with high nickel content and low nickel limonite (Makahanap and Manaf, 2010: 112).

Characterization of the research included Vickers hardness testing, endurance with ASTM E23 05 standard using CMTS model CI-30 impact testing machine, microstructure to determine the phase formed using MEIJI techno MT7100 metallurgical microscope and fracture observation using JEOL JSM-6390A SEM.

The austempering heat treatment process requires two furnaces. The first furnace serves to heat the test sample to a temperature of $9500 \mathrm{C}$ and hold time for 60 minutes to obtain an even or homogeneous austenite phase. The second furnace for the austempering process using a cooling medium Zinc element which is melted at temperatures above martensite start. In this study, the temperature of austempering used was $4500 \mathrm{C}$ with variations in holding the time or holding time of 30.60 and 90 minutes.

The cooling media used is liquid metal. Basically liquid metal can maintain its melting point at certain temperatures because the range of metals also has a range between the melting point and the vapor point. As used in this study, the zinc metal element ( $\mathrm{Zn})$ where zinc has a chemical property as follows:

1. Molecular weight $: 65,39 \mathrm{~g} / \mathrm{mole}$

2. Color : Bluish-grey

3. Melting point $\quad: 419^{\circ} \mathrm{C}\left(786.2^{\circ} \mathrm{F}\right)$

4. Boiling point $\quad: 907^{\circ} \mathrm{C}\left(1664.2^{\circ} \mathrm{F}\right)$

\section{RESULTS AND DISCUSSION}

\subsection{IMPACT STRENGTH}

Data obtained from Charpy impact testing on variations of holding time 0 minutes, 30 minutes, 60 minutes, and 90 minutes were $209 \mathrm{~J}, 247.6 \mathrm{~J}$, $194 \mathrm{~J}$, and $191.3 \mathrm{~J}$.

Table I. Impact Test Results

\begin{tabular}{|c|c|c|c|c|}
\hline \multicolumn{5}{|c|}{ Impact Test Value, Joule (J) } \\
\hline & $\mathbf{1}$ & $\mathbf{2}$ & $\mathbf{3}$ & Mean \\
\hline Raw Material A10 & 210 & 208 & 0 & 209 \\
Austempering 30 munite A3 & 254 & 242 & 247 & 247.6 \\
Austempering 60 munite A6 & 186 & 192 & 204 & 194 \\
Austempering 90 munite A9 & 196 & 192 & 186 & 191.3 \\
\hline
\end{tabular}

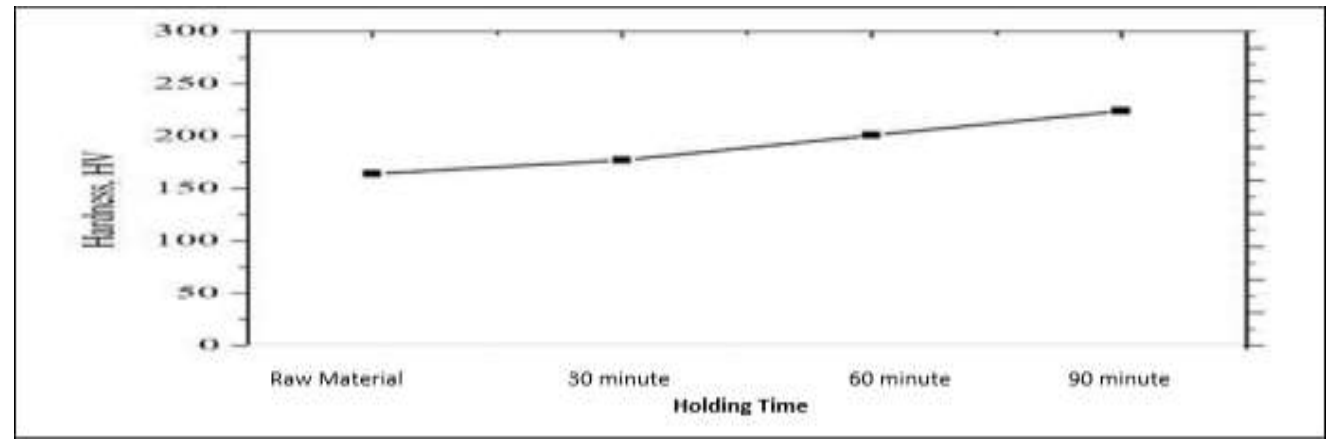

Fig. 2 Impact test graph 
It can be seen in the impact test results that the highest impact resistance value occurred at a time variation of 30 minutes which reached $247.6 \mathrm{~J}$ or increased by $18.46 \%$ for sample A0 or raw material, this was due to the finer ferrite-pearlite structure formed and proved that the transformation of the ferrite-pearlite phase into bainite has begun to appear. Whereas the material with a 60 minute holding time has decreased the impact resistance value to $194 \mathrm{~J}$ or a decrease of $7.17 \%$ for the raw material as well as the sample holding time of 90 minutes decreases the impact resistance value produced which reaches $191.3 \mathrm{~J}$ or decreases by $8,46 \%$ of raw material. This happens because of the presence of the bainite phase which begins to form in the material with a holding time of 60 minutes and 90 minutes. Based on Figure 2, it can be seen that the longer the holding time or holding time lasts, the energy that can be absorbed by the test material decreases due to the increasing number of bainite structures formed. As stated by Reddy in his research, the longer the austempering holding time, the stronger the level of resistance due to the formation of a more homogeneous bainite structure which will cause the level of material hardness to rise and reduce the toughness of laterite steel material.

\subsection{VICKERS HARDNESS}

Data from the hardness test results on the austempering heat treatment process samples increased the value of the hardness that continues to increase. The data obtained from the testing of VAIC hardness in the variation of length of holding the time or holding time at 0 minutes, 30 minutes, 60 minutes, and 90 minutes were $164 \mathrm{HV}, 177 \mathrm{HV}, 201 \mathrm{HV}$, and $224 \mathrm{HV}$.

Table II. Results of Hardness Testing

\begin{tabular}{|c|c|c|c|c|}
\hline \multicolumn{5}{|c|}{ Hardness Value, HV } \\
\hline No & Sample A0 & Sample A3 & Sample A6 & Sample A9 \\
\hline 1 & 161 & 167 & 199 & 232 \\
2 & 165 & 175 & 199 & 239 \\
3 & 163 & 188 & 202 & 202 \\
4 & 167 & 175 & 26 & 210 \\
5 & 166 & 181 & 202 & 239 \\
\hline Average & 164 & 177 & 201 & 224 \\
\hline
\end{tabular}

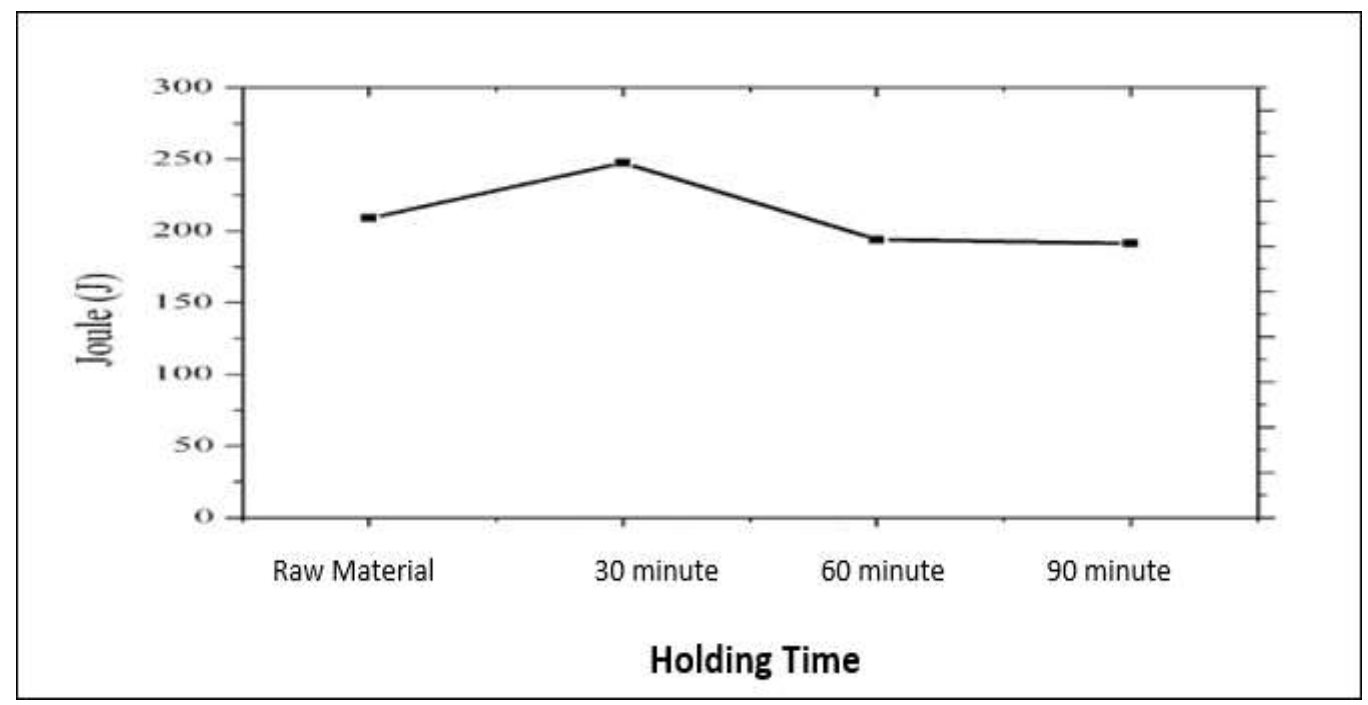

Fig. 3 Graph of the results of the hardness test 
The highest hardness value was generated in a variation of 90 minutes holding time which reached $224 \mathrm{HV}$, this result increased by $36.58 \%$ for raw material samples, this occurred because there was already a bainite structure formed. Where the structure of bainite has a hardness value above the ferrite-pearlite structure which on average only has a hardness value of $70 \mathrm{HV}-150 \mathrm{HV}$, but the hardness does not exceed the martensitic structure which can reach an average of $400 \mathrm{HV}$ - $513 \mathrm{HV}$ (Totten, 2006). While for material samples with a holding time variation of 60 minutes having $201 \mathrm{HV}$ hardness or increasing by $14.02 \%$ on raw material samples which only have $164 \mathrm{HV}$ hardness, this shows that the microstructure of bainite has begun to form with the longer holding time given. In sample A3 has a hardness of $177 \mathrm{HV}$ or an increase of 7.92 raw material and still has a phase formed in A3 samples or at a 30 minute holding time which is ferritepearlite but has been finer and denser than raw material samples this proves that it has begun the phenomenon of the transformation of austenite into bainite. Based on Figure 3, there is an increase in the hardness of the material with the longer duration of detention, the value of the hardness increases even though it is not too significant, but it can form bainite microstructure, this can be proven from the metallographic results in Figures 4 to 7. 8 to 11 it is clearly seen that the longer the holding time, the dimple holes formed, the less it proves that the material increases the hardness value or becomes brittle. As stated by Najeeb (2014) the higher the temperature and the length of time the austempering can increase its hardness.

\subsection{MICROSTRUCTURE}

Analysis of data in the form of Figures 4 to 7 shows raw material samples from metallographic tests showing the raw material of laterite steel has a microstructure in the form of ferrite and pearlite, as stated by Totten (2006) that steel material with $0.2 \%$ carbon content has a ferrite microstructure perlite while the laterite steel material which is in the process of heat treatment austempering with a holding time variation has a different structure. For A3 microstructure steel specimens in the form of pearlite ferrite with fine grains then specimen A6 has a microstructure in the form of pearlite ferrite bainite matrix plate shape and specimen A9 the microstructure is a pearlite ferrite bainite matrix. Metallographic testing shows that the holding time variation in the austempering heat treatment process affects the microstructure of the steel. The longer holding time, the more bainite structure is formed.
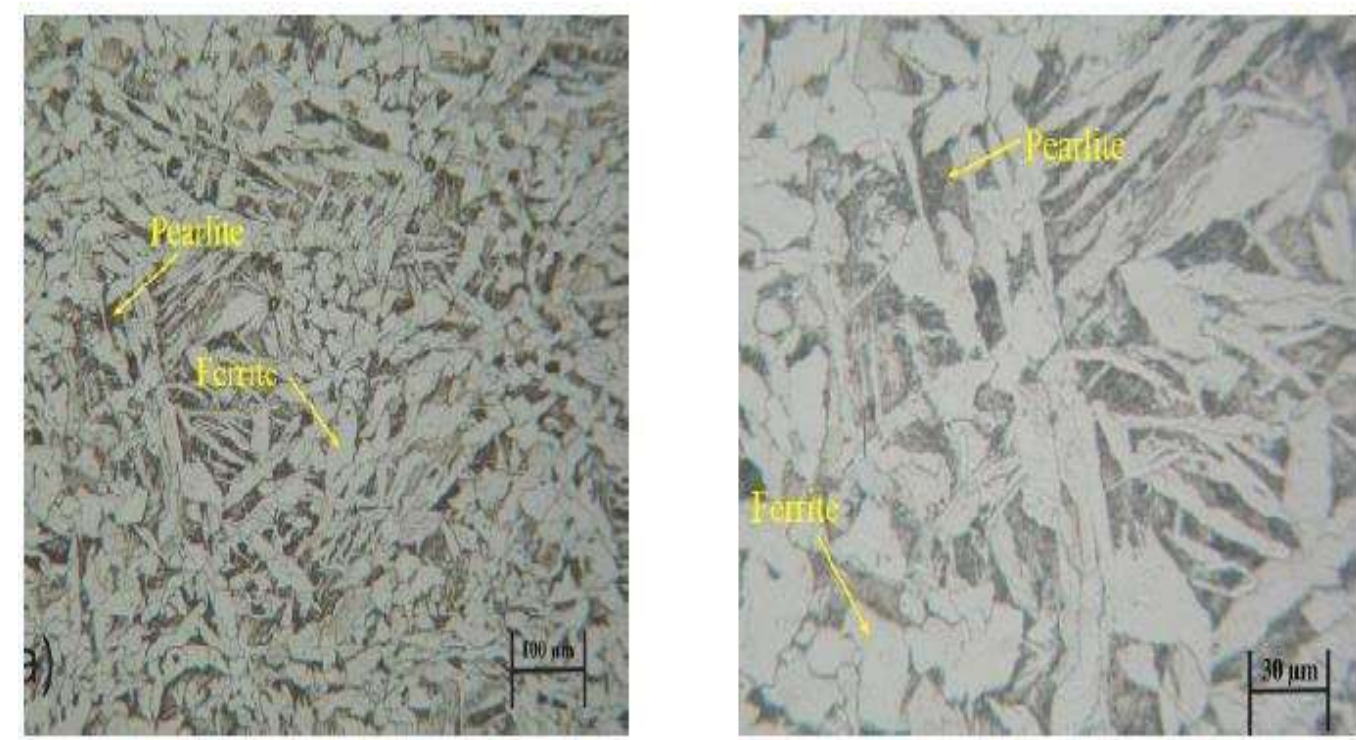

Fig. 4 Metallographic Result A0 

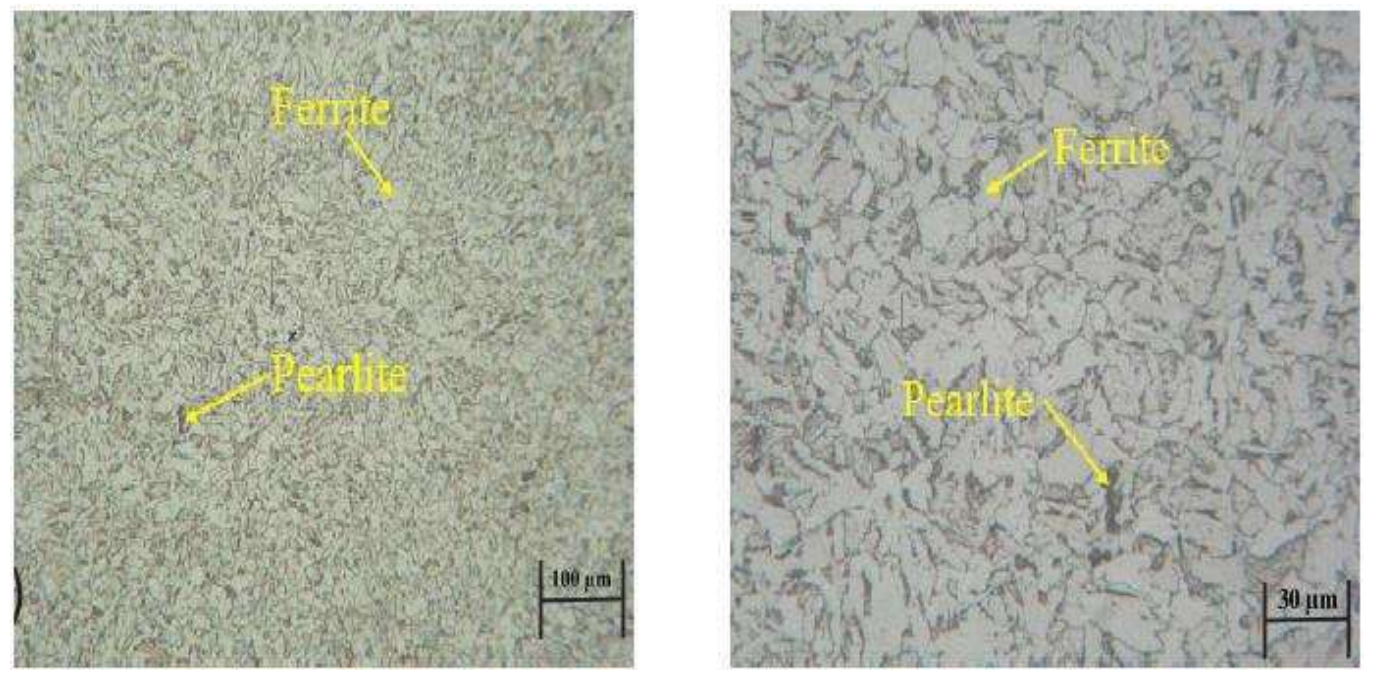

Fig 5 Metallographic Result A3
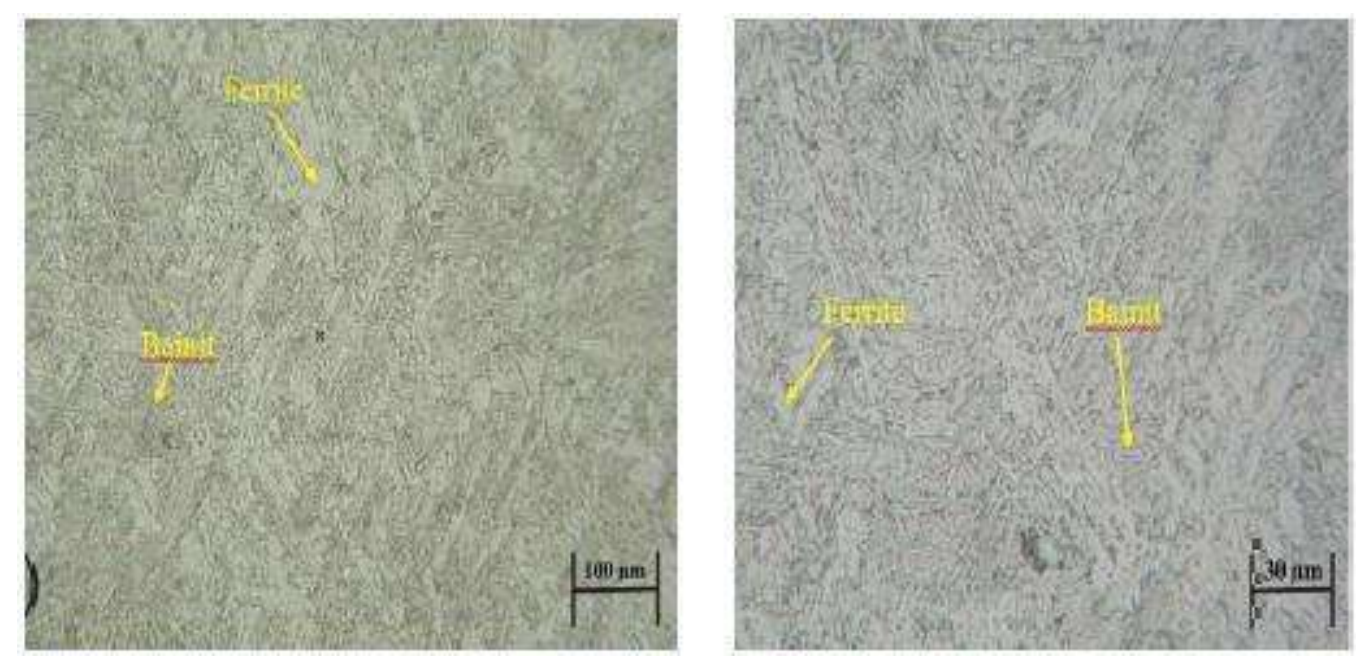

Fig 6 Metallographic Result A6
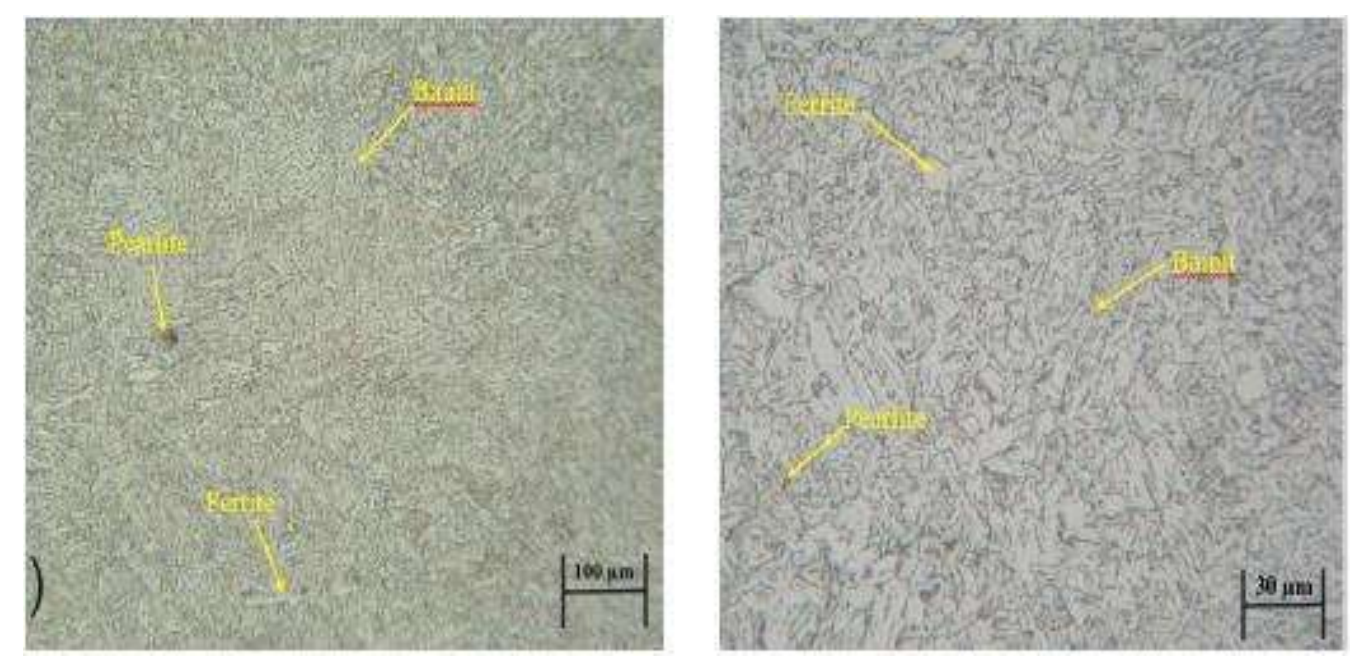

Fig. 7 Metallographic Result A9 
Specimens with heat treatment austempering at a 30 minute holding time still have ferrite-pearlite microstructure but already have a fine grain shape it is evident that the transformation process of the austenite phase into bainite has occurred, but with a holding time of only 30 minutes phase formation is not yet clear bainite, while at holding time 60 and 90 minutes bainite microstructure has begun to be seen because the phase transformation from austenite to bainite has entered the bainite region, as in the Andrew study (2013) said the longer the holding time in the austempering process the more bainite structure formed.

From the content of $\mathrm{Ni}$ which has a weight percent of $1.564 \%$, nickel which dissolves in ferrite forms an fcc unit cell (austenite stabilizer) and decreases the temperature of eutectoid (Yang, Williams, \& Goldstein, 1996). Ferrite-soluble nickel increases toughness, decreases 50\% $\left({ }^{\circ} \mathrm{C}\right)$ of Fracture Appearance Transition Temperature (FATT), even at subzero temperatures (Totten, 2007).

\subsection{SEM-EDS}

SEM testing aims to see fractures formed in raw materials and materials with the austempering heat treatment process.

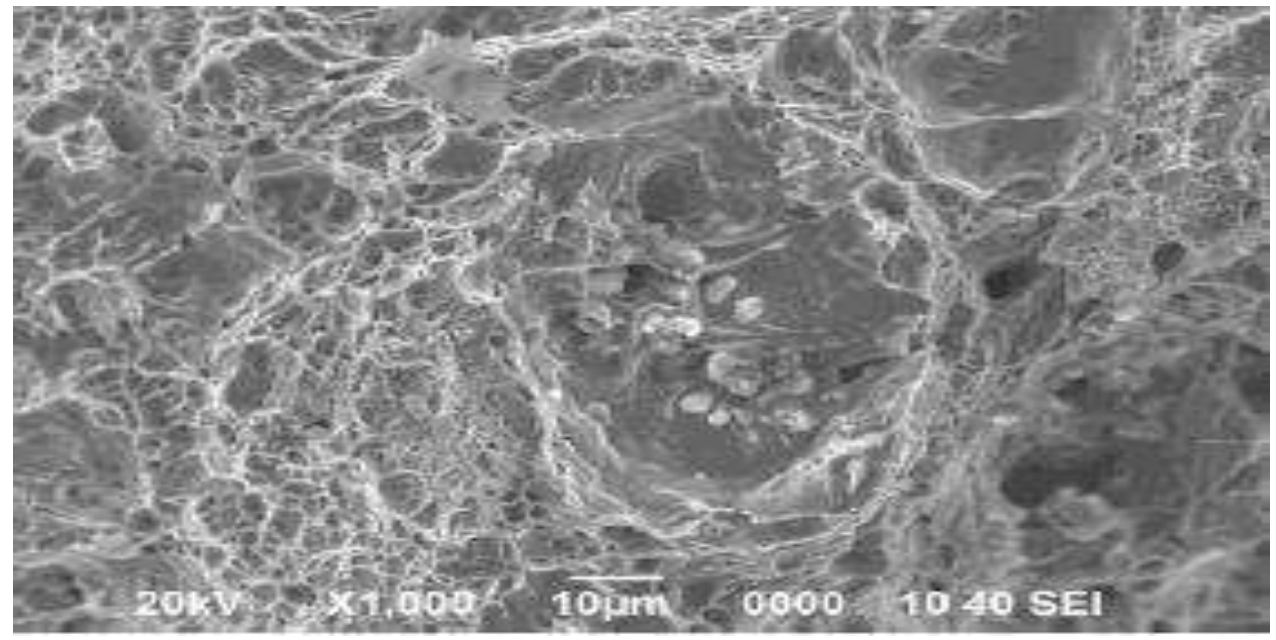

Fig. 8 Result of Impact Fracture A0

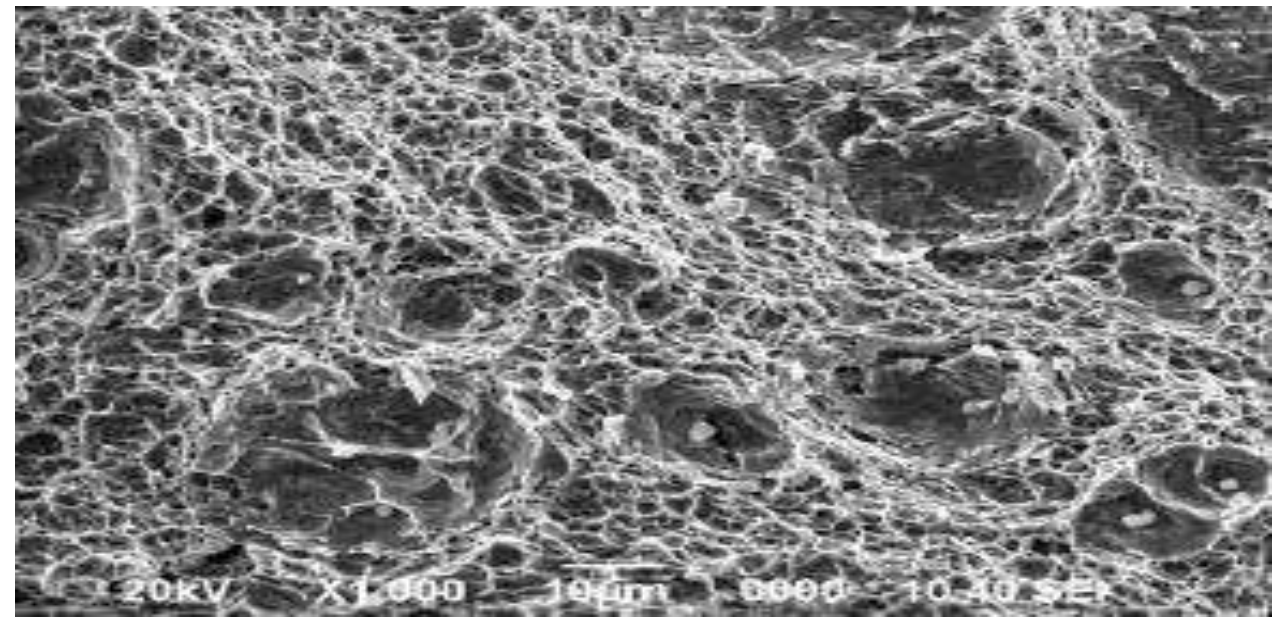

Fig 9 Result of Impact Fracture A3 


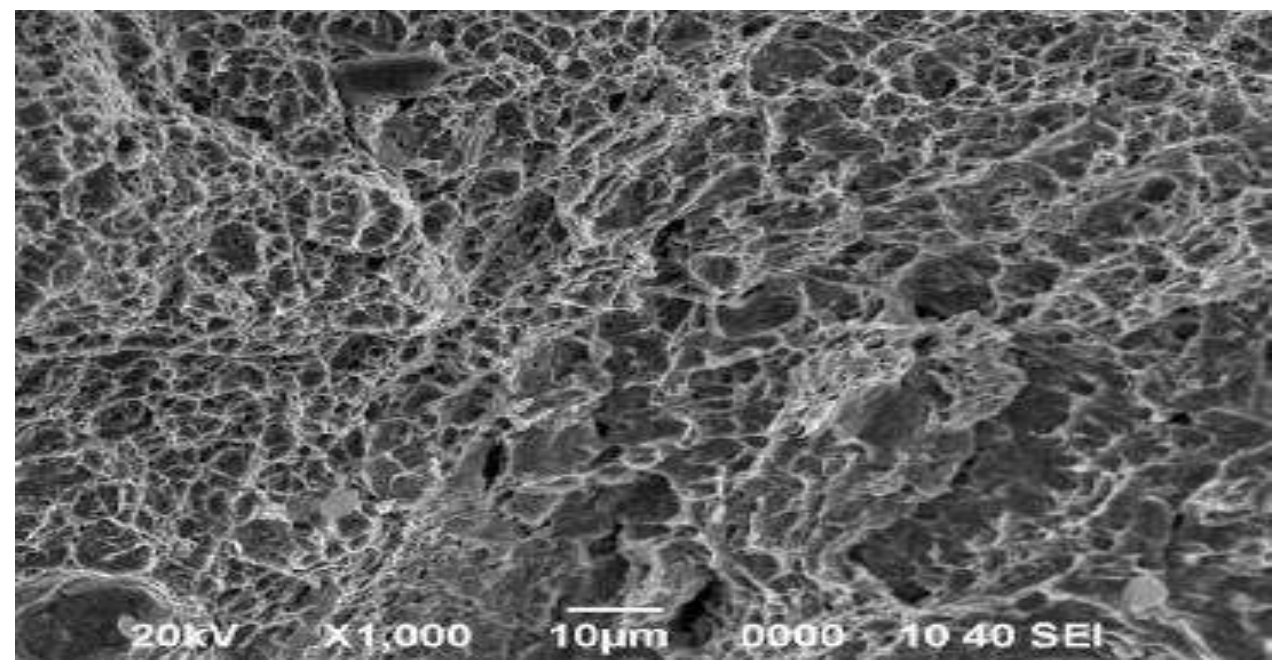

Fig. 10 Result of Impact Fracture A6

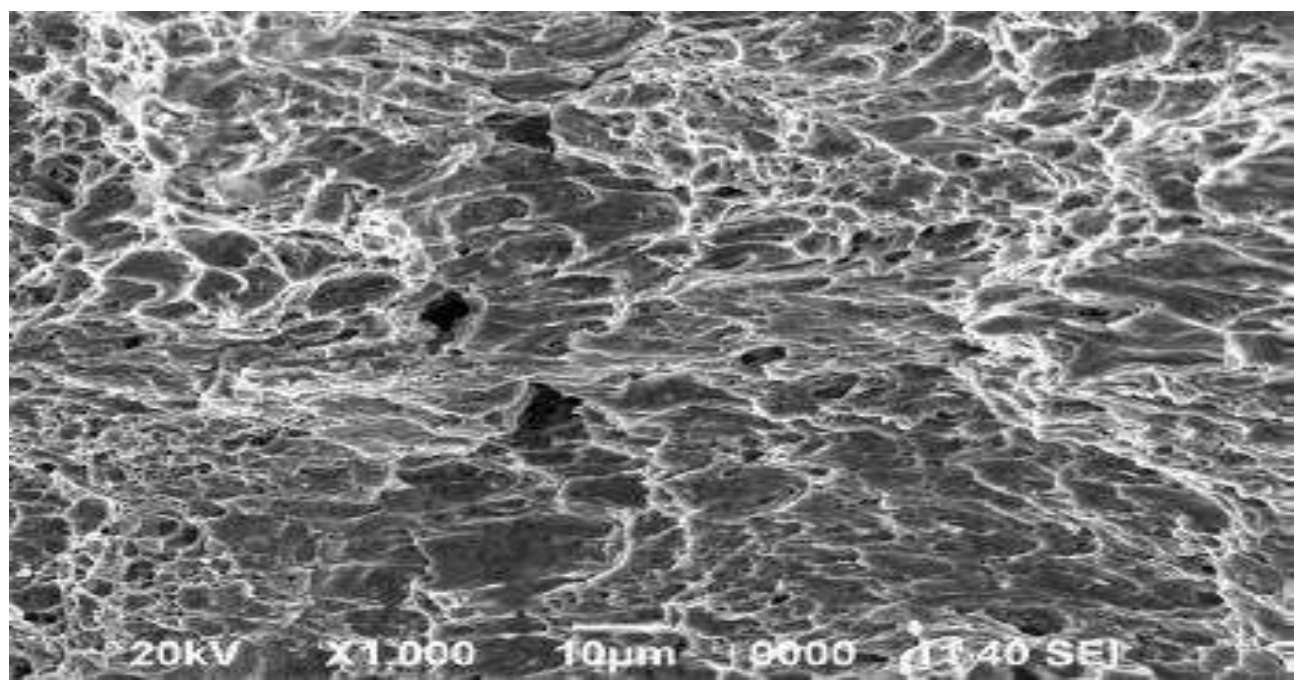

Fig. 11 Result of Impact Fracture A9

The resulting fracture in each material both raw material and after the heat treatment process is included in the type of ductile fracture, as seen from the highest hardness value obtained only $224 \mathrm{HV}$ and the impact resistance value only reaches $247.6 \mathrm{~J}$ the value is still classified as the type of fracture resilient, can be seen from the phase formed is the bainite phase which has a type of ductile fracture, but there is no martensitic phase which has the result of brittle fracture because it has a high hardness value and low impact resistance value. Each sample provides stringent characteristics (fibrous fracture) which involve a mechanism of shifting the crystal field in a ductile metal and absorbing light and dull or dull appearance. This can be seen by the presence of dimple holes as a result of the unification process - small cavity (cavity) during loading takes place (Yuwono, 2009). As stated by Lan et al (2017) in the austempering process a bainite phase is formed which has a type of ductile fracture.

\section{CONCLUSION}

Based on the results of the research conducted, it can be concluded that:

1. Variation in holding time affects the mechanical properties of laterite steel. The increase in hardness in raw material from $164 \mathrm{HV}$ to $224 \mathrm{HV}$ or increased by 
$36.58 \%$ while the impact strength with the longer holding time of energy that can be absorbed by laterite steel is decreasing, ie from sample A0 which initially $209 \mathrm{~J}$ to 247.6 $\mathrm{J}$ in the sample A3, but continued to decline with the longer holding time, from A3 247.6 J to decrease to $194 \mathrm{~J}$ or $27.6 \%$ at A6 and continued to decline to $191.3 \mathrm{~J}$ in the A9 sample or $29.43 \%$.

2. Variation in holding time affects the microstructure of laterite steel. The microstructure transformation from raw material which initially has ferrite-pearlite phase becomes changed in A3 samples which have a finer pearlite ferrite phase as well as samples A6 and A9 which begin the formation of bainite phase although there is still a pearlite ferrite phase and this can also be seen from the fracture impact test that forms a ductile fracture with dimple holes as a result of the process of uniting small cavities during loading.

\section{ACKNOWLEDGMENTS}

This research is original research that has no conflict of interest.

\section{REFERENCES}

[1] ASM International. (2000). ASM Handbook. Volume 8 Mechanical Testing and Evaluation. United States of America: ASM International Handbook Committee.

[2] ASM International. 2004. ASM Handbook. Volume 4 Metallography and Microstructures. United States of America: ASM International Handbook Committee.

[3] Basso, D. Makahanap dan A. Manaf. 2010. Characteristics of Reduction of Laterite Iron Ore. Metallurgical Magazine Journal 25(2): 111-118.

[4] Callister, William D. 1973. Fundamental of Material Science and Engineering. Oxford: Butterworth Heinemann.

[5] Dieter, George E. 1986. Mechanical Metallurgy. $3^{\text {rd }}$ ed. Singapore: McGraw-Hill Book Company.

[6] Haryadi, G. D. 2006. Effect of Tempering Temperature on Hardness, Tensile Strength, and Micro Structures on Steel K-460. Jurnal Rotasi 8(2): 1-8.

[7] Hasbi, M. Yunan, Daniel Panghihutan Malau and Bintang Adjiantoro. 2016. Variations in Reduction of Hardness and Microstructure of Laterite Steel Through Hot Scraping. National Seminar on Science and Technology. Jakarta 2016.

[8] Herbirowo, S., and B. Adjiantoro. 2016. Effect of Heat Treatment on Micro Structures and Mechanical Strength of Laterite Nickel Steel. Jurnal Widyariset 2(2): 153-160.

[9] Ismoyo, A.H., Parikin, and Bandriyana. 2014. Analysis of the Effect of Hot Scraping and Forging Processes on the Mechanical Properties and Micro Structures of ZrNbMoGe Alloys. Journal Urania. 20(1): 14-21.

[10] Murtiono, Arief. 2012. Effect of Quenching and Tempering on Hardness and Tensile Strength and Micro Medium Carbon Steel Structure for Palm Harvesters Knives. e-Dinamis Journal 2(2): 57-70.

[11] Purwanto, H., Rudy Soenoko, Anindito Purnowidodo, and Agus Suprapto. 2015. Macro and Micro Characteristics of Steel-Aluminum Plate against Ballistic Resistance. Prosiding SNST $6^{\text {th }}$ Year 2015. Faculty of Engineering, Wahid Hasyim University: Semarang (97-102).

[12] Smallman, R.E., and R. J. Bishop. 1995. Modern Physical Metallurgy and Materials Engineering. $6^{\text {th }}$ Edition. New Zealand: Reed Educational and Professional Publishing Ltd.

[13] Sugiyono. 2012. Quantitative, Qualitative, and R \& D Research Methods. Bandung: Alfabeta.

[14] Surdia T., and Kenji Chijiiwa. 2000. Metal Casting Technique. Second edition. Eighth print. Jakarta: Pradinya Paramita.

[15] Totten, G, E. 2007. Steel Heat Treatment Metallurgy and Technologies. 2nd ed. U.S.A: Taylor \& Francis Group.

[16] Yuwono, A.H. 2009. Practical Guidebook for Material Characterization 1 Testing Damages (Destructive Testing). Jakarta: Departemen Metalurgi dan Material Universitas Indonesia. 
International Journal of Advanced Science and Technology Vol.131 (2019) 